\title{
MRI findings in Tolosa-Hunt syndrome (THS)
}

\author{
Rodrigo Sánchez Vallejo, ${ }^{1}$ Antonio Lopez-Rueda, ${ }^{1}$ Ana Maria Olarte, ${ }^{2}$ Luis San Roman ${ }^{1}$
}

${ }^{1}$ Department of Radiology, Hospital Clinic i Provincial de Barcelona, Barcelona, Spain ${ }^{2}$ Department of Radiology, Hospital Universitario Sagrat Cor, Barcelona, Spain

\section{Correspondence to}

Antonio Lopez-Rueda, alrueda81@hotmail.com

Accepted 21 October 2014

\section{DESCRIPTION}

A 36-year-old man with no medical history, consulted for a 2-week onset right-sided retro-orbital pain associated with diplopia. On neurological examination the patient had combined ipsilateral third and fourth cranial nerve palsy and hypoesthaesia in the distribution of $\mathrm{V} 1$ of the trigeminal nerve.

Brain MRI demonstrated abnormal enlargement and enhancement of the right cavernous sinus (CS) extending through the superior orbital fissure into the orbital apex (figure 1). Other infectious, inflammatory, neoplastic and vascular entities involving the CS were excluded by appropriate investigations. The painful ophthalmoplaegia had a prompt response to steroid therapy (within $72 \mathrm{~h}$ ) and follow-up brain MRI demonstrated significant improvement (figure 1).

Tolosa-Hunt syndrome (THS $)^{1}$ is an idiopathic inflammatory granulomatous process involving the
CS with possible extension into the superior orbital fissure and orbital apex. The inflammation causes extrinsic compression of the neurovascular structures that cross the CS. THS clinical presentation consists of relapsing unilateral painful ophthalmoplegia, which is responsive to steroid therapy. ${ }^{2}$

Gadolinium-enhanced MRI is the imaging modality of choice to evaluate THS and may demonstrate abnormal enlargement and enhancement of the CS extending through the superior orbital fissure into the orbital apex. Reported MRI findings on T1-weighted and T2-weighted images are extremely variable and non-specific. ${ }^{3}$

MRI plays a pivotal role in diagnosing and helps to exclude other common lesions involving the CS, avoiding the need for high-risk invasive procedures such as a biopsy of the SC, the only way to obtain the histopathological confirmation of this disease.

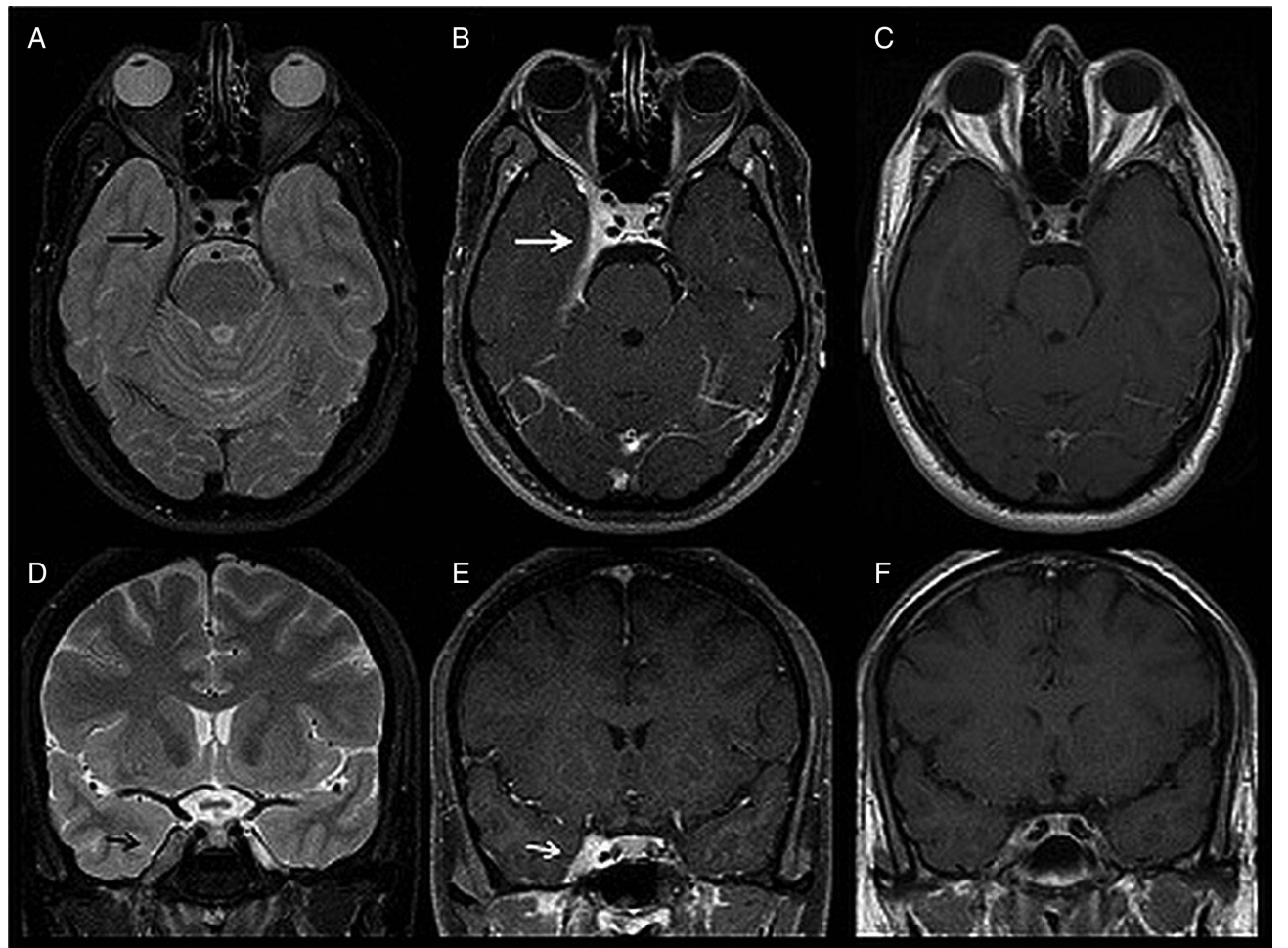

Figure 1 MRI finding of a 36-year-old male patient with right-sided Tolosa-Hunt syndrome. Axial (A) and coronal (D) T2-weighted images (WI) show an enlarged right cavernous sinus (CS) that is mildly hypointense to grey matter (black arrow). Axial (B) and coronal (E) postcontrast T1-weighted fat-suppressed images show the enhancement of the abnormal soft tissue extending through the superior orbital fissure into the orbital apex (white arrow). Also noted is the hyperenhanced thickening of the right temporal dura, tentorium and right orbital apex. Axial (C) and coronal (F) postcontrast T1-WI follow-up, performed one month later, show significant improvement of right-sided CS abnormal enlargement and enhancement.
To cite: Sánchez Vallejo $R_{\text {, }}$ Lopez-Rueda A, Olarte AM, et al. BMJ Case Rep Published online: [please include Day Month Year] doi:10.1136/bcr-2014206629 


\section{Learning points}

- Tolosa-Hunt syndrome (THS) diagnosis is based on clinical manifestations, rapid response to steroids, MRI findings and exclusion of other causes of cavernous sinus (CS) involvement.

- Gadolinium-enhanced MRI is the imaging modality of choice to evaluate the THS and may demonstrate abnormal enlargement and enhancement of the CS extending through the superior orbital fissure into the orbital apex.
Competing interests None.

Patient consent Obtained.

Provenance and peer review Not commissioned; externally peer reviewed.

\section{REFERENCES}

1 La Mantia L, Curone M, Rapoport AM, et al. Tolosa-Hunt syndrome: critical literature review based on IHS 2004 criteria. Cephalalgia 2006;26:772-81.

2 Razek AA, Castillo M. Imaging lesions of the cavernous sinus. AJNR Am J Neuroradiol 2009;30:444-52.

3 Schuknecht B, Sturm V, Huisman TA, et al. Tolosa-Hunt syndrome: MR imaging features in 15 patients with 20 episodes of painful ophthalmoplegia. Eur J Radiol 2009;69:445-53.

Copyright 2014 BMJ Publishing Group. All rights reserved. For permission to reuse any of this content visit http://group.bmi.com/group/rights-licensing/permissions.

BMJ Case Report Fellows may re-use this article for personal use and teaching without any further permission.

Become a Fellow of BMJ Case Reports today and you can:

- Submit as many cases as you like

- Enjoy fast sympathetic peer review and rapid publication of accepted articles

- Access all the published articles

- Re-use any of the published material for personal use and teaching without further permission

For information on Institutional Fellowships contact consortiasales@bmjgroup.com

Visit casereports.bmj.com for more articles like this and to become a Fellow 